\title{
Evaluation of Serum Lipid Profile of Under-Five Nigerian Children
}

\author{
${ }^{1}$ S. A. Akuyam, ${ }^{1}$ H. S. Isah and ${ }^{2}$ W. N. Ogala \\ Departments of ${ }^{1}$ Chemical Pathology and ${ }^{2}$ Paediatrics, Ahmadu Bello University Teaching Hospital, Zaria, \\ Nigeria \\ Reprint requests to: Dr. S. A. Akuyam, Department of Chemical Pathology, A. B. U. Teaching Hospital, \\ P. M. B. 1026, Zaria, Nigeria.E-mail: shehuakuyam@yahoo.com
}

\begin{abstract}
Background: Serum lipid profile assay forms one of the special investigations in most chemical pathology laboratories worldwide. Several studies in children from different countries have shown that serum lipids exhibit age and geographical pattern of variation prior to puberty. This study was conducted to evaluate serum lipid profile in Nigerian children aged 6 to 36 months.

Methods: A total of 115 randomly selected apparently healthy children were studied. These consisted of 38,40 and 37 children in groups I (6 to 12 months), II (13 to 24 months) and III ( 25 to 36 months) respectively. There were 60 male and 55 female children. Serum concentrations of total cholesterol (TC), high density lipoprotein cholesterol (HDL-C), triglyceride (TG) were measured by enzymatic colorimetric method using reagent kits supplied by Human, Gesel Für Biochemica Und Diagnostica mbH (Wiesbaden, Germany). Serum low density lipoprotein cholesterol (LDL-C) and very low density lipoprotein cholesterol (VLDL-C) were subsequently estimated using Friedewald formula.

Results: The reference ranges and (Mean \pm SEM) of serum TC, LDL-C, HDL-C, TG, VLDL-C and TC/HDL-C for the total group of children were 1.55-5.42(2.89 \pm 0.12$), 0.50-3.29(1.28 \pm 0.15), 0.45-$ $2.77(1.12 \pm 0.14), 0.93-3.43(0.79 \pm 0.14), 0.17-0.72(0.35 \pm 0.14) \mathrm{mmol} / \mathrm{L}$ and $1.01-4.74(2.19 \pm 0.13)$ respectively. There were no sex differences in all these parameters. Serum levels of TC, LDL-C, HDL-C and TC/HDL-C in the 3 age groups were also statistically similar ( $p>0.05)$. Concentrations of TG and VLDL-C were lower $(\mathrm{p}<0.001)$ in group II than in I. These values were also significantly lower $(p<0.02)$ in group III than in I. Serum TG and VLDL-C in groups II and III were statistically comparable $(\mathrm{p}>0.05)$.

Conclusion: Serum concentrations of TC, TG and VLDL-C decrease with advancing age, with more marked decrease between first and second years of life. We hereby recommend that the reference values established in this study be utilized for the interpretation of serum lipid results in pre-school children in Nigerian hospitals and possibly elsewhere in Africa.
\end{abstract}

Keywords: Serum lipids, under-fives, reference values

\section{Résumé}

Introduction: Essai sur le profil des lipides du sérum constitue une des enquêtes spéciales dans la plupart des laboratoires de la pathologie chimique dans le monde entire. Des études diverses sur plusieurs pays ont indiqué que les lipides du sérum montre une tendance d'âge et géographique des variation avant la puberté. Cette étude a été effectuée afin d'évaluer le profil de lipide sérum chez des enfants nigérians âges de 6 à 36 mois.

Méthodes: Un total de 15 enfants choisis au hasard apparemment d'une très bonne santé ont été étudié. Ils se composent de 38,40 et 37 enfants du prémier groupe (6 au 12 mois), deuzièm groupe (13 au 24 mois) et troisièm groupe ( 25 au 36 mois) respectivement. Il y avait 60 enfants du sexe masculin et 55 enfants du sexe féminin. Concentration du sérum du cholestérol total (TC), la densité élevée cholestérol lipoprotein (HDL-C), triglyceride (TG) ont été mésurés à travers la méthode colorimétrique enzymatique à travers l'utilisation des équipements réactifs fournis par Huam, Gesel Fur Biochemical Und Diagnostica mbH (Wiebaven, Germany). Lipoprotein cholestérol du sérum avec une densité inférieure (LDL-C) et lipoprotein cholestérol d'une densité très inférieure (VLDL-C) ont été par la suite calculé avec l'utilisation de formule de FriedeWald.

Résultats: La référence de l'ordre et (moyen +-SEM) du sérum TC, LDL-C, HDL-C, TG, VLDL-C et TC/HDL-C pour le groupe total des enfants étaient 1,55-5, 42(2,89+-0,12), 050-3,29 (1,28+-0,15), 0,45$2,77(1,12+-0,14), 0,93-, 43(0,79+-0,14), 0,17-0$. 72(0,35+-0,14) $\mathrm{mmol} / \mathrm{L}$ et $0,01-4,74(2,19+-0,13)$ respectivement. Il n'y avait aucune différence du sexe dans tous les paramètres. Niveaux du sérum de 
TC, LDL-C HDL-C et TC/HDL-C dans les trois groupes d'age étaient également statistiquement semblable $(p>0,05)$. Concentrations du TG et VLDL-C étaient moins $(p<0,001)$ dans le deuxiem groupe plus que dans le prémier groupe. Ces valeurs étaient remarquablement inférieur $(p<0,02)$ dans le troisiem plus que dans le prémier groupe. Sérum TG et VLDL-C dans le deuxièm et troisièm groupe était statistiquement comparable $(\mathrm{p}>0,05)$

Conclusion: Concentrations du sérum de TC, TG et VLDL-C diminue avec l'âge qui s'avance, avec une diminution plus remarquable entre le prémier et deuxièm an de la vie. Donc, nous proposons que des valeurs de référence soulignées dans cette étude peuvent être utlisées pour l'inteprétation des résultats du lipide du sérum chez des enfants préscolaires dans des hôpitaux nigérians et peut être ailleurs en Afrique.

Mots clés: Lipide de sérum, âgés de moin de cinq ans, valeurs de référence

\section{Introduction}

Serum lipid profile assay forms one of the special investigations in most chemical pathology laboratories worldwide. The importance of the assay is fast increasing in many developing countries, including Nigeria. Lipid profile assay has found useful application in the management of patients with cardiovascular diseases ${ }^{1}$ and monitoring of patients with diabetes mellitus. ${ }^{2-4}$ It is also important in the assessment of obese individuals, alcoholics and individuals of high social status ${ }^{5}$ as well as in the assessment of malnourished children. ${ }^{6-9}$

Serum lipids are under multifactorial control where both genetic and environmental factors influence the levels of these parameters in children and adults. 10, 11 Types of food have also had a significant influence, where high levels of saturated fats in the diet elevate serum lipids. ${ }^{12}$ Several studies in children from different countries have shown considerable variations in serum lipids. ${ }^{13-16}$ These studies confirmed that serum lipids exhibit age and geographical pattern of variation prior to puberty. It is well documented that serum lipids are directly related to age. ${ }^{15-17}$ Several reports around the world show a fluctuation in serum lipids prior to puberty. ${ }^{15-17}$

Considering that serum lipids are lower in children than in adults, there is the need to have a separate reference value for children. To date only few laboratories in developing countries have reference values for children. The aim of this study was to measure serum lipids in apparently healthy Nigerian children with a view to establishing the reference ranges for these analytes, as well as to determining the pattern of serum lipids in relation to age and sex during early childhood period.

\section{Materials and Methods}

The study was conducted in Ahmadu Bello University Teaching Hospital (ABUTH), Zaria, northern Nigeria. This study was approved by the Ethical Committee of the ABUTH, Zaria in accordance with the declaration of Helsinki. A total of 115 apparently healthy children aged 6 to 36 months attending Paediatric Out-Patient Department (POPD) clinic were consecutively recruited. These were selected from the population of children presenting with mild ailments such as colds and fever, which are not known to affect serum lipid concentrations. The determination of sample size was based on $95 \%$ confidence interval as recommended, whereby the theoretical minimum sample size of 40 observations is considered valid. ${ }^{18,19}$ However, to ensure precision of the percentiles, increasing the sample size to about 100 is usually acceptable ${ }^{18,20}$. Therefore a sample size of 115 subjects was considered for this study to ensure better precision. Since most biometric data are not distributed in Gaussian manner, non-parametric statistics was employed for analysis of the results.

The subjects were grouped into three different age groups, as groups I (6-12 months), II (13-24 months) and III (25-36 months) with 38, 40 and 37 children respectively. There were 60 male and 55 female children. Informed consent for inclusion into the study was obtained from the parents/guardians of the selected children. All children whose parents/guardians declined to give consent for inclusion were excluded from the study. The nature of the study was explained to the parents/guardians in the appropriate language. Personal data and a full medical history were obtained from the parents/guardians of any selected child.

Blood specimens were taken into plain tubes using a sterile technique. Blood was centrifuged and the serum was carefully drawn into sample bottle and then stored frozen at $-20^{\circ} \mathrm{C}$ until the time for analysis. Serum concentrations of total cholesterol (TC), high density lipoprotein cholesterol (HDL-C) and triglyceride (TG) were measured by enzymatic colourimetric method using reagent kits supplied by Human, Gesel Für Biochemica Und Diagnostica mbH (Wiesbaden, Germany). Serum low density lipoprotein cholesterol (LDL-C) and very low density lipoprotein cholesterol (VLDL-C) were subsequently estimated using Friedewald formula. ${ }^{21}$ The results were stratified according to different sex and age categories. The data were analyzed using SPSS 9.0 for Windows (SPSS Inc., Chicago, IL) statistical program. The results were log-transformed and the sum of the mean plus or minus two times standard deviation ( $\sum \log$ mean $\pm 2 \log \mathrm{SD}$ ) was used to establish the reference ranges for the analytes. Student's t-test was employed for the comparison of serum lipids between males and females, whereas one way analysis of variance (ANOVA) was employed for the comparison of the results obtained from children at different age groups. A p-value of equal to or less than 0.05 ( $\mathrm{p} \leq$ 0.05 ) was considered as statistically significant. 


\section{Results}

The reference ranges and (mean \pm SEM) of serum lipids for the total group of children are shown in Table 1. The differences in the values between males and females were not significant $(p>0.05)$. Table 2 shows serum lipid levels in children classified by age groups. The results in this table show that TC, LDL-C, HDL-C concentrations and TC/HDL-C ratios in the 3 groups were statistically similar $(\mathrm{p}>0.05)$. Serum TG and VLDL-C were significantly higher $(\mathrm{p}<0.001)$ in group I than in II. These values were also significantly higher in group I than in III $(p<0.02)$. TG and VLDL-C values in groups II and III were statistically comparable $(p>0.05)$ but apparently higher in group II than in III.

Serum concentrations of TC, TG and VLDL-C decrease with advancing age, with more pronounced decrease between first and second years of life.

Table 1: Serum lipids (Mean \pm SEM and reference values) and sex in apparently healthy Nigerian children

\begin{tabular}{|c|c|c|c|c|c|c|c|}
\hline Subjects & $\mathrm{n}$ & $\begin{array}{l}\mathrm{TC} \\
(\mathrm{mmol} / \mathrm{L})\end{array}$ & $\begin{array}{l}\text { LDL-C } \\
(\mathrm{mmol} / \mathrm{L})\end{array}$ & $\begin{array}{l}\text { HDL-C } \\
(\mathrm{mmol} / \mathrm{L})\end{array}$ & $\begin{array}{l}\text { TG } \\
(\mathrm{mmol} / \mathrm{L})\end{array}$ & $\begin{array}{l}\text { VLDL-C } \\
(\mathrm{mmol} / \mathrm{L})\end{array}$ & $\begin{array}{l}\mathrm{TC} / \mathrm{HDL}-\mathrm{C} \\
\text { (atherogenic } \\
\text { index) }\end{array}$ \\
\hline \multicolumn{8}{|l|}{ Males } \\
\hline Mean \pm SEM & & $2.85 \pm 0.16$ & $1.18 \pm 0.19$ & $1.14 \pm 0.19$ & $1.80 \pm 0.18$ & $0.36 \pm 0.18$ & $2.03 \pm 0.17$ \\
\hline Reference & & $1.59-5.11$ & $0.51-3.13$ & $0.45-2.90$ & $0.85-3.78$ & $0.17-0.74$ & $1.02-4.03$ \\
\hline \multicolumn{8}{|l|}{ values } \\
\hline Females & 55 & & & & & & \\
\hline Mean \pm SEM & & $2.93 \pm 0.17$ & $1.18 \pm 0.25$ & $1.11 \pm 0.22$ & $1.88 \pm 0.25$ & $0.35 \pm 0.21$ & $2.41 \pm 0.20$ \\
\hline Reference & & $1.58-5.47$ & $0.52-3.17$ & $0.44-2.79$ & $0.76-3.66$ & $0.15-0.82$ & $1.10-4.57$ \\
\hline \multicolumn{8}{|l|}{ values } \\
\hline Total $(\mathrm{M}+\mathrm{F})$ & 115 & & & & & & \\
\hline Mean \pm SEM & & $2.89 \pm 0.12$ & $1.28 \pm 0.15$ & $1.12 \pm 0.14$ & $0.79 \pm 0.14$ & $0.35 \pm 0.14$ & $2.19 \pm 0.13$ \\
\hline Reference & & $1.55-5.42$ & $0.50-3.29$ & $0.45-2.77$ & $0.93-3.43$ & $0.17-0.72$ & $1.01-4.74$ \\
\hline \multicolumn{8}{|l|}{ values } \\
\hline $\mathrm{p}$-value & & $>0.05$ & $>0.05$ & $>0.05$ & $>0.05$ & $>0.05$ & $>0.05$ \\
\hline
\end{tabular}

Table 2: Serum lipids (Mean \pm SEM and reference values) and age in apparently healthy Nigerian children

\begin{tabular}{|c|c|c|c|c|c|c|c|}
\hline Age group & $\mathrm{n}$ & $\begin{array}{l}\mathrm{TC} \\
(\mathrm{mmol} / \mathrm{L})\end{array}$ & $\begin{array}{l}\text { LDL-C } \\
(\mathrm{mmol} / \mathrm{L})\end{array}$ & $\begin{array}{l}\text { HDL-C } \\
(\mathrm{mmol} / \mathrm{L})\end{array}$ & $\begin{array}{l}\text { TG } \\
(\mathrm{mmol} / \mathrm{L})\end{array}$ & $\begin{array}{l}\text { VLDL-C } \\
(\mathrm{mmol} / \mathrm{L})\end{array}$ & $\begin{array}{l}\text { TC/HDL-C } \\
\text { (atherogenic } \\
\text { index) }\end{array}$ \\
\hline Group I & 38 & & & & & & \\
\hline Mean \pm SEM & & $3.09 \pm 0.21$ & $1.39 \pm 0.27$ & $1.22 \pm 0.28$ & $2.17 \pm 0.23$ & $0.42 \pm 0.23$ & $2.36 \pm 0.23$ \\
\hline Reference & & $1.75-5.43$ & $0.56-3.42$ & $0.49-3.02$ & $1.28-3.66$ & $0.23-0.77$ & $1.11-4.98$ \\
\hline values & & & & & & & \\
\hline Group II & 40 & & & & & & \\
\hline Mean \pm SEM & & $2.79 \pm 0.15$ & $1.24 \pm 0.19$ & $1.06 \pm 0.18$ & $1.64 \pm 0.17$ & $0.32 \pm 0.17$ & $2.14 \pm 0.16$ \\
\hline Reference & & $1.49-5.24$ & $0.47-3.30$ & $0.44-2.58$ & $0.87-3.10$ & $0.16-0.66$ & $1.01-4.53$ \\
\hline values & & & & & & & \\
\hline Group III & 37 & & & & & & \\
\hline Mean \pm SEM & & $2.81 \pm 0.43$ & $1.24 \pm 0.54$ & $1.04 \pm 0.55$ & $1.59 \pm 0.51$ & $0.28 \pm 0.48$ & $2.26 \pm 0.50$ \\
\hline Reference & & $1.27-5.92$ & $0.46-3.30$ & $0.38-2.86$ & $0.87-2.92$ & $0.14-0.58$ & $1.01-5.03$ \\
\hline \multicolumn{8}{|l|}{ values } \\
\hline \multirow[t]{3}{*}{ p-value } & & $>0.05$ & $>0.05$ & $>0.05$ & $*<0.001$ & $*<0.001$ & $>0.05$ \\
\hline & & & & & $* *<0.02$ & $* *<0.02$ & \\
\hline & & & & & $* * *>0.05$ & $* * *>0.05$ & \\
\hline
\end{tabular}

*: Between groups I and II; **: Between groups I and III; ***: Between groups II and III

TC: Total cholesterol; LDL-C: Low density lipoprotein cholesterol; HDL-C: High density lipoprotein cholesterol; TG: Triglyceride; VLDL$\mathrm{C}$ : Very low density lipoprotein cholesterol

\section{Discussion}

Reference values of serum lipids have been established for one hundred and fifteen apparently healthy children aged 6 to 36 months in Zaria, northern Nigeria. Over the last 2 to 3 decades, extensive research carried out in different developed countries had provided significant evidence that 
children of different ages and from different

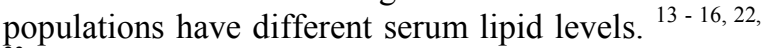

${ }^{23}$ However, to the best of our knowledge, there are very scanty reports on the pattern of serum lipids in children in African countries, including Nigeria. The findings of this study could therefore serve as a challenge to clinical chemists and paediatricians elsewhere in Africa to undertake such studies.

The levels of all the serum lipid parameters were apparently higher in the first year compared to the second and third. This suggests that serum lipids decrease with advancing age in children during preschool period. These findings are in agreement with the previously published reports from other parts of the world. ${ }^{16,23-26}$ Results obtained in this study were lower than those reported in India, 15, 23 Finland, Netherlands, Italy and Philippines but similar to those in Ghanaian children. ${ }^{13}$ Serum TC values found in the present study were lower and serum TG higher than those obtained in Saudi children. ${ }^{16}$ These variations may well be due effect of race, geography and diet.

The findings of the present study concerning reference values of serum lipids in children are consistent with the general knowledge on factors affecting biochemical analytes world-wide. Factors such as age, geographical location, diet, extent of exercise regimen, obesity, life style and genetic influence both adult and paediatric lipid levels. ${ }^{27,} 28$ The most crucial factors in children under this study could be probably diet and genetics. From age one year, serum lipids fluctuate until around 15 years after which they remain stable through to old age. ${ }^{26}$ This fluctuation could be due to different dietary regimen. 24, 29 Babies on human-milk-substitute formula are typically shown to have lower lipid levels than those on cows-milk and breast-fed babies having higher levels until they start a mixed diet. ${ }^{25,26}$

The type of association between age and serum lipids found in this study could be related to the type of diet and feeding regimen of the children. It is known that effective and probably exclusive breastfeeding take place within the first and possibly the second years of childhood period. It is also known that breast-milk is the most suitable source of all nutrients, including cholesterol (CHOL) and TG required for the development of the newborns. Infantformula differs from human-milk in their chemical compositions, with lower concentrations of lipids than in breast-milk. ${ }^{30}$ Therefore, as the children are weaned and their routine diets change to formula and mixed food, which may be low in these lipids, serum lipids will start to decrease. This is consistent with the findings of decrease in serum CHOL and TG with advancing age in the present study.

It can be suggested from the findings of this study that each population must establish its own reference values for serum lipids for the better management of affected subjects. Considering the fact that serum lipids change with advancing age up to 15 years, separate reference values are needed for the other categories of children. Children could be aged grouped to conform with standard paediatric care and reference values be established for each group as the pre-term neonates, full-term neonates, infants (1-12 months), pre-school (1-5 years) and school/prepubertal age (6-12 years) reference values.

The reference values established in the present study can be utilized for the interpretation of serum lipid results in pre-school Nigerian children, and perhaps elsewhere in Africa.

\section{Acknowledgment}

The authors thank the entire staff of the Chemical Pathology and Paediatrics Department of the Ahmadu Bello University Teaching Hospital, Zaria, Nigeria. The Ahmadu Bello University Board of Research provided financial assistance.

\section{References}

1. Low PS, Saha N, Tay TS, et al. Ethnic variation of cord plasma apolipoprotein levels in relation to coronary risk level: a study in three ethnic groups of Singapore. Acta Paediatr 1996; 85: 1476-1482

2. Ferreira SR, Iunes M, Franco LJ, et al. Disturbances of glucose and lipid metabolism in first and second generation Japanese-Brazilians. Japanese-Brazilian diabetes study group. Diabetes Res Clin Pract 1996; 34 (Suppl): 59-63

3. Poirier P, Catellier C, Tremblay A, et al. Role of body fat loss in the exercise-induced improvement of the plasma lipid profile in noninsulin dependent diabetes mellitus. Metabolism 1996; 45: 1383-1387

4. Kramer-Guth A, Quaschning T, Greiber S, et al. Potential role of lipids in the progression of diabetic nephropathy. Clin Nephrol 1996; 46:262-265

5. Buemann B, Tremblay A. Effect of exercise training on abdominal obesity and related metabolic complications. Sport Med 1996; 21: 191-212

6. Ogunkeye OO, Ighogboja IS. Increase in total serum triglyceride and phospholipid in kwashiorkor. Ann Trop Paediatr 1992; 12:463466

7. Houssaini FZ, Foulon T, Iraqi MR, et al. Lipids, lipoproteins and fatty acids during infantile marasmus in the Fes area of Morocco. Biomed Pharmacother 1999; 53:278-283

8. Kimak E, Solski J, Janicka L. Lipoprotein profiles at different stages of chronic renal insuffieiency. Ren Fail 2000; 22:63-71

9. Taskinen MH, Antikainen M, Saarinen-pihkala UM. Skeletal muscle protein mass correlate with lipid status in children with solid tumours and before bone marrow transplantation. Eur J Clin Nutr 2000; 54:219-224

10. Tejada C, Strong JP. Distribution of coronary aortic atherosclerosis by geographic location, race and sex. Lan Invest 1968; 18:509-526

11. McGill HC Jr (ed). The geographic pathology of atherosclerosis. Williams and Wilkins, Baltimore, 1968

12. Holman R. Atherosclerosis: a paediatric nutrition 
problem. Am J Clin Nutr 1961; 9:565-569

13. Knuiman JT, Westenbricks S, Van der H, et al. Determinant of total and high density lipoprotein cholesterol in boys from Finland, the Netherlands, Italy, the Phillipines and Ghana with special reference to diet. Hum Nutr Clin Nutr 1983; 3:237-354

14. Wynders EL, Williams CL, Laakso $\mathrm{K}$, et al. Screening for risk factors for chronic disease in children from fifteen countries. Prev Med 1981; 10:121-132

15. Khalil A, Gupta S, Madam A, et al. Lipid profile norms in Indian children. Indian Pediatr 1995; 32:1177-1180

16. El-Hazmi MAF, Warsy AS. Evaluation of serum cholesterol and triglyceride levels in 1-6 years Saudi children. J Trop Paediatr 2001; 47:181-185

17. Das SC, Isichei UP. Beta lipoprotein cholesterol, beta lipoprotein and triglycerides in a healthy Nigerian population. Niger Postgrad Med J 1997; 4:88-92

18. Solberg HE. Establishment and use of reference values. In: Tietz NW (Ed.). Text book of clinical chemistry. Saunders, Philadelphia, 1986; 356-386

19. Reed AH, Henry RJ, Mason WB. Influence of statistical method used on the resulting estimate of normal range. Clin Chem 1971; 17: 275-84.

20. Petersen PH. Guest essay: the latest on reference values and reference intervals. Rev Clin Chem Lab Med 2004; 42: 1-10

21. Friedewald WT, Levy RI, Fredrickson DS. Estimation of the concentration of low density lipoprotein cholesterol in plasma without the use of preparative ultracentrifugation. Clin Chem $1972 ; 18: 499$
22. Kuiterovich PO Jr. Plasma lipids and lipoprotein levels in childhood. Ann NY Acad Sci 1991; 623:90-107

23. Wajid AS, Buch NA, Masood H. Serum lipid profile in Kashmiri children. Indian $\mathrm{J}$ Physiol Pharmacol 1995; 39:55-58

24. Boediman D, Murakami R, Nakamura H, et al. Plasma apolipoproteins in the first year of life. Kobe J Med Sci 1989; 35:165-176

25. Kallio MJ, Salmenpera L, Siimes MA, et al. Exclusive breastfeeding and weaning: effect on serum cholesterol and lipoprotein concentrations in infants during the first year of life. Pediatrics 1992; 89:663-669

26. John B. Screening of hypercholesterolaemia in childhood. In: Hypercholesterolaemia of the child. Annales Nestle 1994; 52:14-24

27. Laner RM, Lee J, Carte WR. Factors affecting the relationship between childhood and adult cholesterol: the Muscatine study. Pediatrics 1988; 82:309-318

28. Webber LS, Hunter SM, Johnson CC, et al. Smoking, alcohol and oral contraceptives effects on lipids during adolescence and young adulthood-Bogalusa heart study. Ann NY Acad Sci 1991; 623:135-154

29. Kirstein D, Johansen KB, Peterson MV, et al. Changes in plasma lipoproteins from first day to third week of life in healthy breast-fed infants. I. Lipid and protein composition of lipoprotein. Acta Pediatr Scand 1985; 74:733-737

30. Maslanka R, Siemianowicz K, Stajszezyk M, et al. Effect of feeding methods in infants on serum lipid profile. Pediatr Pol 1995; 70: 579-583 